\title{
Self-Directedness for Sustainable Learning in University Studies: Lithuanian Students' Perspective
}

\author{
Nijolè Burkšaitiene ${ }^{1} \mathbb{D}$, Robert Lesčinskij ${ }^{2}$, Jelena Suchanova ${ }^{2}$ and Jolita Šliogeriene ${ }^{2, *(\mathbb{C}}$ \\ 1 Department of Translation Studies, Faculty of Philology, Vilnius University, 01513 Vilnius, Lithuania; \\ nijole.burksaitiene@flf.vu.lt \\ 2 Department of Foreign Languages, Faculty of Creative Industries, Vilnius Gediminas Technical University, \\ 10223 Vilnius, Lithuania; robert.lescinskij@vilniustech.lt (R.L.); jelena.suchanova@vilniustech.lt (J.S.) \\ * Correspondence: jolita.sliogeriene@vilniustech.lt
}

check for

updates

Citation: Burkšaitienè, N.; Lesčinskij, R.; Suchanova, J.; Šliogerienè, J. Self-Directedness for Sustainable Learning in University Studies: Lithuanian Students' Perspective. Sustainability 2021, 13, 9467. https://doi.org/10.3390/su13169467

\section{Academic Editors:}

Fermin Sanchez-Carracedo, Jordi Segalàs Coral and Gemma Tejedor

Received: 30 June 2021

Accepted: 20 August 2021

Published: 23 August 2021

Publisher's Note: MDPI stays neutral with regard to jurisdictional claims in published maps and institutional affiliations.

Copyright: (c) 2021 by the authors. Licensee MDPI, Basel, Switzerland. This article is an open access article distributed under the terms and conditions of the Creative Commons Attribution (CC BY) license (https:// creativecommons.org/licenses/by/ $4.0 /)$.

\begin{abstract}
The paper analyzes Lithuanian students' preparedness for sustainable learning from the perspective of self-directedness. The data for the study were collected using a questionnaire that explored students' perceptions in line with ten indicators of self-directed learning. The research sample $(n=309)$ was composed of the third and fourth year undergraduates accomplishing their degrees in various areas of studies. The data analysis revealed how students perceive their readiness for sustainable learning. Goal setting, technical readiness, time management, procrastination management, exam preparation and stress management indicators were analysed in detail in order to determine which variables had the most significant impact on these indicators. The study revealed that the students are only partially prepared for sustainable learning at the university. Even though they have the necessary digital competencies that allow for effective involvement in the learning process, the data revealed that they are prone to procrastination. The results also showed that the students perceived themselves to be the least competent in stress management and procrastination management.
\end{abstract}

Keywords: self-directedness; sustainable learning; higher education; university studies; online learning

\section{Introduction}

The COVID-19 pandemic has caused many challenges that have stretched far beyond the medical and economic sectors. Educational organizations have been forced to review the established educational practices, including the curricula, which has resulted in numerous changes at all levels of education, including higher education (hereinafter-HE). Recent international research has revealed alarming trends indicating that the number of students postponing graduation has increased [1], graduate readiness to enter the labour market has declined [2], entry into some study programmes has slowed down [3] and learning outcomes have deteriorated [4]. The pandemic has also negatively impacted learners physical and psychological well-being [2,5].

Online learning has become a lifeline for HE. However, not all university communities are well prepared for this challenge because the transition to such learning requires both the digitization of the curricula and learners' preparedness. Learners have to become engaged in online learning, which requires a high level of self-directedness. The response to this challenge can be to develop students' capability for sustainable learning. The concept of sustainable learning is still relatively new in the field of HE research. The early calls for sustainable education [6-8] focused on the need for systematic changes within the education systems worldwide in order to help drive the development of the economies towards a more sustainable future. The most recent studies in the field of HE research [9] define sustainable learning as learning that persists and can be transferred to other areas of life and that stretches beyond the context of university education as the learner can detect meaningful learning experiences outside of academia [9]. Such learning, similar to lifelong 
and lifewide learning, goes beyond the acquired knowledge and developed skills. Instead, it is learning characterized by the continuous and purposeful development of the learner's ability to anticipate the need for the knowledge necessary for the future. On the other hand, it draws on the idea of "unlearning" of the knowledge no longer required, which allows the learner to improve and change the available "knowledge capital" actively.

Education research suggests that the concept of sustainable learning has not yet been thoroughly explored as a phenomenon because there exist substantial knowledge gaps when it comes to the interpretation of this phenomenon and its importance for a contemporary university. One of those gaps is related to the lack of research into student self-directedness for sustainable learning in HE. To the best of our knowledge, to date, research into student preparedness for sustainable learning from the perspective of selfdirectness as perceived by the students themselves has not yet been conducted. The present study was carried out to fill in this research gap. It contributes to this field of research by exploring Lithuanian students' preparedness for sustainable learning from the perspective of their self-directedness, which renders the current research unique in Lithuania even though its scope does not allow for wide generalization as it was conducted with the participation of only four Lithuanian universities. The aim of the present research is to establish the university students' preparedness for sustainable learning. To reach this aim, two following research objectives were set: The first research object is to analyse the extent of the students' self-directedness by investigating their perspectives on the indicators of self-directed learning as defined by Khiat [10]. The indicators included the following: goal setting, technical readiness, time management, procrastination management, notemaking capability, assignment preparation, research capability, online class readiness, exam readiness and stress management. The second research objective was to reveal the student-perceived challenges for self-directedness.

The present paper reports on the results of the research starting from a literature review, followed by the description of the research method. Then, the results are presented and discussed, and the implications for further research are outlined. Finally, conclusions are drawn.

\section{Literature Review}

\subsection{Transformative Learning for Sustainability in Higher Education}

Nowadays, the new roles of education and, in particular, the new role of HE have been widely analysed. It has been recognised that HE should contribute to the creation of a sustainable world and that in order to foster sustainability in HE, pedagogies should result in the shift from the learning process aimed at equipping students with the required knowledge and skills towards the learning process that educates students in becoming capable of determining their learning needs and to continuously develop them after leaving academia. In this context, transformative learning is pivotal. It can be viewed as an element of sustainable learning as it is based on active student participation in the process of learning, directed towards understanding the meaning of what is being learnt. It requires constant reflecting on what has been achieved and how one can improve; thus, it can be seen as learning "required to deconstruct the existing ways of knowing and understanding" [11] (2769), which can help the learners move beyond the established practices, adapt to the constantly changing expectations and critically assess problems encountered in their professional careers.

The relevant literature illustrates that sustainability in HE can be achieved by making changes to study programmes and curricula [9-14], by fostering learners' competencies for sustainable development such as problem solving, critical and creative thinking, action competence and systems thinking [15-18] and by introducing pedagogies that foster transformative learning [19].

According to the leading theorist of transformative learning Mezirow [18], transformative learning "is learning that transforms problematic frames of reference-sets of fixed assumptions and expectations (habits of mind, meaning perspectives, mindsets) — to make 
them more inclusive, discriminating, open, reflective, and emotionally able to change" [18] (58). Central in transformative learning is the distinction between instrumental and communicative learning [18]. The former is described as learning that is "about controlling and manipulating the environment, with emphasis on improving prediction and performance", whereas the latter refers "to understanding what someone means when they communicate with you. This understanding includes becoming aware of the assumptions, intentions and qualifications of the person communicating" (p. 59). Similarly, Sterling [19] notes that learning that is content-focused and that is supported by the pedagogies of information transfer is learning about things, which does not involve deep levels of understanding as it does not question the learner's assumptions or beliefs. It is only when learners are encouraged to critically view their own assumptions and beliefs that they engage in transformative learning.

In their analysis of the nature of transformative learning, Blake, Sterling and Goodson [17] draw on Bateson's model of three levels of learning and point out that the notion of transformative learning can be understood in two ways. On the one hand, it can be seen as learning in which a shift is made from the first level of learning (i.e., from "doing things better") to the second level of learning (i.e., to "doing better things"). On the other hand, it can be understood as learning characterized by a profound shift to the third level of learning (i.e., to "seeing things differently"), which is also called epistemic learning (5351-5352). This is what makes transformative learning particularly relevant for developing students' sustainable learning in HE.

The overview of the relevant literature shows that in order to achieve a shift toward transformative learning in $\mathrm{HE}$, the role of educators and the educator-created conditions that are favourable for change are pivotal. It has been recognized that the main professional goal of the educator is to foster "the learner's skills, habit of mind, disposition, and will to become a more active and rational learner" [18]. This means that teaching should be aimed at supporting and encouraging the learner to adopt the approach to learning which requires active participatory engagement and reflecting on one's learning and achievement. Consequently, the outcomes of such learning reflect deep understanding of what has been learnt and are appropriate for sustainable development [20-24].

The literature also illustrates that due to the complexity of the changes that are a prerequisite for transformative learning to occur in HE, planning, facilitating and implementing them are challenges for all the parties involved, including HE institutions, academics and learners. On the one hand, the process of planning involves significant institutional preparations such as making holistic changes to study programmes and curricula so that HEIs are ready to implement transformative learning [13-15]. On the other hand, to be able to support learners and to facilitate a shift toward transformative learning, teachers themselves should gain the necessary competencies and be ready to adopt changes in pedagogies. For example, they should be prepared to introduce the so-called multi-method approach to learning based on diverse teaching methods (both didactic and constructivist) aimed at fostering learners' competencies for sustainable development [17]. Finally, the implementation of changes is also challenging for learners as it can cause their resistance to or rejection of the changes [17]. Thus, in order to move toward transformative learning successfully, learners should be encouraged to actively engage in the process of learning and be trained to direct their learning. This could result in sustainable learning which involves ongoing, purposeful, responsive and proactive learning where the learner effectively builds and rebuilds his/her knowledge and skills base as circumstances change.

\subsection{Self-Directed Learning in Higher Education}

The emphasis on learners' self-directedness in HE has increasingly grown during the last decades as it is believed to ensure successful participation in the process of studying. Thus, students are presumed to be self-directed learners in academia. However, the literature overview suggests that there is a need to support them in becoming such learners. It is reported that self-directedness is efficient only if learners have developed a self- 
regulated learning approach. It requires them to possess a strategic view on learning and high self-regulated learning skills (to establish their own needs, define distinct learning goals and use relevant methods and materials to achieve these goals) [10,25-28]. Selfdirected learners are those who manage not only to direct their studies but also to accept responsibility, to construct meaning and to cognitively monitor one's learning process [29]. To support students to become fully self-directed learners, the role of a teacher-facilitator is crucial and involves the development of "the self-directed learner as an autonomous and self-regulated learner" [29].

According to Hiemstra [30], self-direction is a term that takes into consideration external factors that motivate learners to take paramount responsibility as well as internal factors that incline learners to accept responsibility for their learning process. Internal and external factors of self-direction are balanced when the learning conditions correspond to self-directed learning opportunities that demonstrates a connection between self-directed learning and learner self-direction. Self-directed learning can be viewed as any accumulation of knowledge, development of skills, completion of tasks or self-development that a learner chooses on his own by using any approach or technique under any conditions at the appropriate time [31].

According to Brookfield [32], the driving force behind self-direction is the importance of the learner's ability to exercise control over all educational decisions. Thus, the learner sets the goals for learning and determines the required resources, methods and the criteria for evaluating the degree of success of any learning experience. In this sense, self-directed learning may be considered as an element of sustainable learning, as defined by Hays and Reinders [6]. According to Hays and Reinders [6], sustainable learning builds on the philosophical foundation of the ideas of Walter Leal Filho et al. [33]. The authors (ibid.) define sustainable learning as learning that is retained (and may be transferable) after initial exposure to it and may involve a process of learning to learn. This implies that learners need to develop their self-directed learning capability, which allows them to identify what knowledge is required and how it may be obtained.

\section{Research Method}

The research sample $(n=309)$ was composed of the third and fourth year undergraduates accomplishing their degrees in various areas of studies, including technological sciences, social sciences and humanities at four universities in Lithuania. Out of the total respondents, $50.8 \%$ were in their third year, while $49.2 \%$ were in their fourth year of studies. A little under $80 \%$ of respondents had some work experience (1- $\geq 5$ years).

The data for the study were collected during the period of January-April 2021 by using the statements from the questionnaire developed by Khiat [10]. The author's permission was sought before launching the survey on Google Forms.

The original questionnaire consisted of 66 questions covering eleven indicators of selfdirectedness that measured students' perceived competence level in self-directed learning. The current study did not consider the questions related to students' preparedness for face-to-face classes/seminars which were under the eleventh indicator [10] (p. 46) as the respondents were studying online. Thus, ten indicators comprising 60 statements were selected for the current research study. In addition, a few open-ended questions complementing the data were included in the questionnaire. The answers to the openended questions will be analysed and presented in forthcoming papers.

The Likert scale ranging from 1 (strongly disagree) to 7 (strongly agree) was used. While computing the results, some values were inverted since some questions were presented in the negative form.

The collected data were analysed using SPSS (Version 25). Descriptive statistics were employed in order to provide summaries about the sample and measure, correlation analysis (Spearman's rho) was performed to determine relationships between the variables and indicators and non-parametric tests (Chi-square, Mann-Whitney U test, Kruskal-Wallis 
$\mathrm{H}$ test) and ANOVA analysis were used to determine statistically significant differences. The significance threshold applied in this study is $p<0.05$.

The research was conducted ethically. The questionnaire did not collect any personal data that could potentially identify the respondents. The preamble to the questionnaire explained the purpose of the questionnaire and informed respondents on the amount of time required to complete the survey. Informed consent was obtained from all subjects involved in the study. The study was conducted according to the guidelines of the Declaration of Helsinki. Ethical review and approval were not necessary.

\section{Results}

In order to establish the consistency of the indicators investigated in the paper, the Cronbach alpha coefficient was calculated, and a high level of internal consistency was established (Cronbach alpha $=0.88$ ). The participants' demographic data regarding their study year, gender or the study programme were excluded from the calculation as they were not significant for the research results.

\subsection{Students' Perspectives on Readiness for Self-Directed Learning}

Data analysis revealed how the students perceived their readiness for self-directed learning according to ten indicators, which are shown in Figure 1.

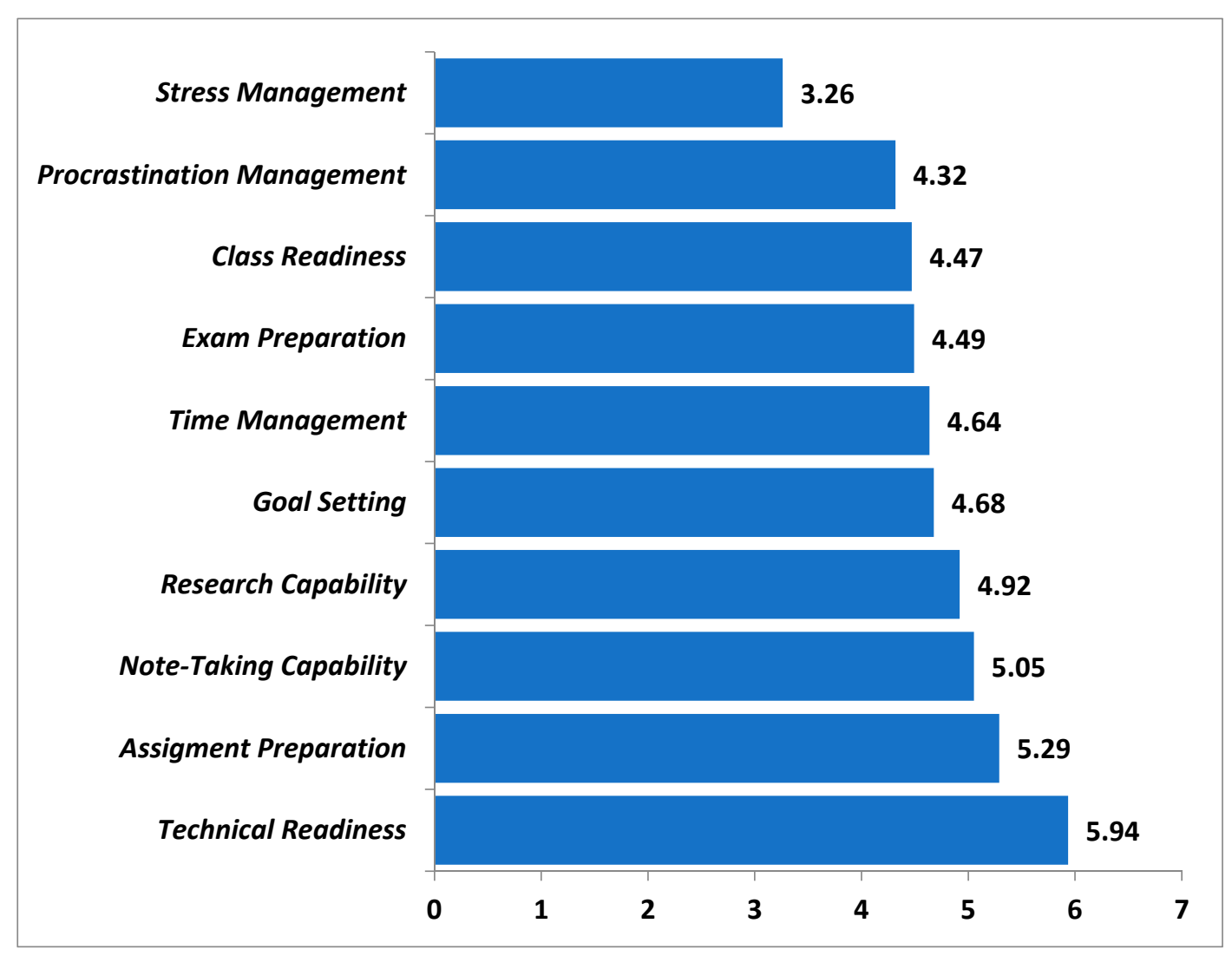

Figure 1. The average scores of self-directed learning indicators.

Most indicators investigated in this study had scores above four (where four-neither agree nor disagree). The only notable exception in this respect was stress management (3.26). The results suggest that the students had confidence (score is $>5$ ) in their notetaking capability (5.05), assignment preparation capability (5.29) and that the extent of their technical readiness was high (5.94). The latter finding was unexpected, since the transition to online learning is commonly associated with challenges of a technical manner by researchers, practitioners and policy makers alike. 
Procrastination management (4.32), class readiness (4.47), exam preparation (4.49), time management (4.64), goal setting (4.68) and research capability (4.92) all had scores between four and five, which may suggest a certain degree of student preparedness regarding these factors of self-directedness; however, it may also hint at the lack of confidence and/or certain difficulties related to these indicators.

The data also suggest certain dependencies. In the age of online learning, assignment preparation and note-taking capabilities may be seen as linked with the students' technical readiness. Statistical analysis also revealed a correlation between technical readiness and note-taking capability ( $r h o=0.236 ; p=0.000$ ) and assignment preparation $(r h o=0.249$; $p=0.000)$.

However, the results showed that technical readiness did not mitigate anxiety and stress caused by online learning. Despite being prepared to deal with the technological challenges of online learning, students nonetheless failed to cope with personal stress.

The students' perceptions regarding their capability of goal setting, technical readiness, time management, procrastination management, exam preparation and stress management were analysed in order to determine the variables attributed to these indicators having the most significant impact on them.

The results of the study showed statistically significant correlations, including the established statistically significant correlation between the main indicators for self-directed learning such as "goal setting", "time management" ( $\left.r h o=0.595^{* *} ; p=0.000\right)$ and "procrastination management" $\left(r h o=0.522^{* *} ; p=0.000\right)$. The variable "goal setting" correlated with all variables (see Table 1), demonstrating that all indicators for self-directed learning had a strong relationship and made an impact on student ability to take control over the learning process.

The statistical analysis (Spearman's rho) of the variables of the indicator "goal setting" disclosed the following ranking of variables: "knowing what to achieve from the programme" (rho $\left.=0.726^{* *} ; p=0.000\right)$, "not knowing why the degree programme has been chosen" (rho $\left.=0.715^{* *} ; p=0.000\right)$, "being at a loss what should be learnt" (rho $\left.=0.676^{* *} ; p=0.000\right)$, "setting targets for assignments and examinations" ( $\left.r h o=0.648^{* *} ; p=0.000\right)$, "seeing the benefits from completing the study programme" (rho $\left.=0.581^{* *}\right)$ and "not monitoring how much has been achieved" (rho $\left.=0.514^{* *} ; p=0.000\right)$.

What is noteworthy is the fact that student technical readiness was not linked with the indicators such as time management, procrastination management or stress management. A statistically significant correlation was found between the variables representing "technical readiness" and "exam preparation" ( $\left.r h o=0.264^{* *} ; p=0.000\right)$, indicating that technical readiness was an important indicator for student self-directedness, particularly during examination sessions.

Further analysis of the variables of the indicator "technical readiness" demonstrated that the variables ranked in the following order: "having problems using computer" (rho $=0.705$ **; $p=0.000)$, "feeling intimidated using the Internet" (rho $\left.=0.693^{* *} ; p=0.000\right)$, "trying to avoid computer-based study work" (rho $\left.=0.657^{* *} ; p=0.000\right)$, "feeling comfortable using a computer" (rho $=0.638$ **; $p=0.000)$, "seeing life more interesting using the internet" (rho $=0.554$ **; $p=0.000)$, "using social media regularly" (rho $\left.=0.397^{* *} ; p=0.000\right)$, etc. The data demonstrate that respondents felt comfortable using the hardware and software required for online learning but are not necessarily comfortable when using social networks.

An investigation into the indicator "time management" revealed that the variables were ranked as follows: "finding time to study materials" (rho $\left.=0.737^{* *} ; p=0.000\right)$, "setting enough time for examinations and assignments" (rho $\left.=0.706^{* *} ; p=0.000\right)$, "not knowing what to study" (rho=0.640**; $p=0.000)$, "not submitting assignments on time" (rho $\left.=0.634^{* *} ; p=0.000\right)$, "planning what to learn" (rho $\left.=0.598^{* * ;} p=0.000\right)$ and "feeling to have too much to accomplish" $\left(r h o=0.552^{* *} ; p=0.000\right)$. While student responses indicate they are able to make time for studying course materials, it seems that the respondents are also prone to postponing some of the assignments until the end of the term. 
Table 1. Correlations between indicators of self-directed learning.

\begin{tabular}{|c|c|c|c|c|c|c|c|c|}
\hline & & & D1_Goal_Setting & D2_Technical_Readiness & D3_Time_Management & D4_Procrastination_Management & D9_Exam_Preparation & D10_Stress_Management \\
\hline \multirow[t]{18}{*}{$\begin{array}{l}\text { Spearman's } \\
\text { rho }\end{array}$} & D1_Goal_Setting & $\begin{array}{l}\text { Correlation } \\
\text { Coefficient }\end{array}$ & 1.000 & $0.165^{* *}$ & $0.595^{* *}$ & $0.522 * *$ & $0.434^{* *}$ & $0.347^{* *}$ \\
\hline & & Sig. (2-tailed) & & 0.004 & 0.000 & 0.000 & 0.000 & 0.000 \\
\hline & & $\mathrm{N}$ & 309 & 309 & 309 & 309 & 309 & 309 \\
\hline & $\begin{array}{l}\text { D2_Technical_ } \\
\text { Readiness }\end{array}$ & $\begin{array}{l}\text { Correlation } \\
\text { Coefficient }\end{array}$ & $0.165^{* *}$ & 1.000 & $0.142 *$ & -0.029 & $0.264^{* *}$ & 0.041 \\
\hline & & Sig. (2-tailed) & 0.004 & & 0.012 & 0.610 & 0,000 & 0.472 \\
\hline & & $\mathrm{N}$ & 309 & 309 & 309 & 309 & 309 & 309 \\
\hline & $\begin{array}{c}\text { D3_Time_ } \\
\text { Management }\end{array}$ & $\begin{array}{l}\text { Correlation } \\
\text { Coefficient }\end{array}$ & $0.595^{* *}$ & $0.142 *$ & 1.000 & $0.611^{* *}$ & $0.429 * *$ & $0.310^{* *}$ \\
\hline & & Sig. (2-tailed) & 0.000 & 0.012 & & 0.000 & 0.000 & 0.000 \\
\hline & & $\mathrm{N}$ & 309 & 309 & 309 & 309 & 309 & 309 \\
\hline & $\begin{array}{l}\text { D4_Procrastination_ } \\
\text { Management }\end{array}$ & $\begin{array}{l}\text { Correlation } \\
\text { Coefficient }\end{array}$ & $0.522^{* *}$ & -0.029 & $0.611^{* *}$ & 1.000 & $0.209^{* *}$ & $0.332^{* *}$ \\
\hline & & Sig. (2-tailed) & 0.000 & 0.610 & 0.000 & & 0.000 & 0.000 \\
\hline & & $\mathrm{N}$ & 309 & 309 & 309 & 309 & 309 & 309 \\
\hline & $\begin{array}{l}\text { D9_Exam_- } \\
\text { Preparation }\end{array}$ & $\begin{array}{l}\text { Correlation } \\
\text { Coefficient }\end{array}$ & $0.434^{* *}$ & $0.264^{* *}$ & $0.429^{* *}$ & $0.209^{* *}$ & 1.000 & $0.404^{* *}$ \\
\hline & & Sig. (2-tailed) & 0.000 & 0.000 & 0.000 & 0.000 & & 0.000 \\
\hline & & $\mathrm{N}$ & 309 & 309 & 309 & 309 & 309 & 309 \\
\hline & $\begin{array}{c}\text { D10_Stress_ } \\
\text { Management }\end{array}$ & $\begin{array}{l}\text { Correlation } \\
\text { Coefficient }\end{array}$ & $0.347^{* *}$ & 0.041 & $0.310^{* *}$ & $0.332^{* *}$ & $0.404^{* *}$ & 1.000 \\
\hline & & Sig. (2-tailed) & 0.000 & 0.472 & 0.000 & 0.000 & 0.000 & \\
\hline & & $\mathrm{N}$ & 309 & 309 & 309 & 309 & 309 & 309 \\
\hline
\end{tabular}

**. Correlation is significant at the 0.01 level (2-tailed). *. Correlation is significant at the 0.05 level (2-tailed). 
The variables attributed to the indicator "procrastination management" were ranked as follows: "finding excuses for not studying" (rho $=0.789^{* *} ; p=0.000$ ), "keeping postponing tasks" (rho $\left.=0.768^{* *} ; p=0.000\right)$, "preferring doing other things instead of studying" (rho $=0.748$ **; $p=0.000)$, "following study schedule" (rho =0.704 **; $p=0.000)$, "persisting in finishing uncompleted tasks" $\left(r h o=0.545^{* *} ; p=0.000\right)$ and "finding studying for a course a priority" $(r h o=$ $\left.0.526^{* *} ; p=0.000\right)$. These results are in line with the findings discussed for the previous indicator, i.e., the students admit postponing assignments until the end of the term. Such procrastination creates time management problems.

The variables attributed to the indicator "exam preparation" were ranked as follows: "feeling confident taking tests and examinations" (rho $=0.742 * * ; p=0.000)$, "doing badly in tests and examinations" ( $\left.r h o=0.716^{* *} ; p=0.000\right)$, "not understanding questions in tests and examinations" (rho $\left.=0.708^{* *} ; p=0.000\right)$, "being able to complete tests and examinations" ( $r$ ho = $\left.0.686^{* *}\right)$, "being able to remember facts and knowledge" (rho $\left.=0.620^{* *} ; p=0.000\right)$ and "being nervous during examinations" (rho $=0.544^{* *}, p=0.000$ ). The sample consisted of the third and fourth year students who, at this stage of studies, are expected to know how to prepare for examinations. However, the data analysis reveals that some students still performed badly in tests and exams and that taking tests still caused some stress.

It has already been reported that the only indicator that was remarkably distinctive was that of "stress management"; thus, every single variable attributed to this indicator was analysed separately (see Table 2).

The obtained results showed that the students who felt motivated whenever they studied loved attending classes $\left(r h o=0.610^{* *} ; p=0.000\right)$. However, despite being motivated, they were also physically exhausted ( $\left.r h o=0.410^{* *} ; p=0.000\right)$, or they feared that they were not performing well for their assignments ( $\left.r h o=0.249^{* *} ; p=0.000\right)$. A statistically significant correlation was established between the variables measuring students' fear of not performing well for tasks and not meeting the expectations in their studies ( $r h o=$ $\left.0.597^{* *} ; p=0.000\right)$, suggesting that the students felt stressed while studying online and lost confidence if the set goals were not reached. The analysis of the variables attributed to the indicator "stress management" revealed that the variables were ranked as follows: "Fear of not doing well" (rho $\left.=0.634^{* *} ; p=0.000\right)$, "feel motivated" (rho $\left.=0.632{ }^{* *} ; p=0.000\right)$, "demoralized when not meeting the expectations" (rho $\left.=0.5722^{* *} ; p=0.000\right)$, "physically drained" ( rho $\left.=0.553^{* *} ; p=0.000\right)$, "love attending classes" ( rho $\left.=0.491^{* *} ; p=0.000\right)$ and "not worry about not submitting" (rho $=0.388^{* *} ; p=0.000$ ) (see Table 2$)$.

The authors agree that the dependencies investigated above may have been influenced by certain demographic factors, one of which is student work experience. Since the current paper finds sustainable learning encompassing both lifelong and life-wide learning, exploring the impact of student activities work experience may shed some light on how student self-directedness is influenced by their involvement in work organizations.

The results of the present study demonstrate that a vast majority of the surveyed respondents had some work experience (see Table 3).

Furthermore, the Kruskal-Wallis $\mathrm{H}$ test performed on the data showed that depending on the students' work experience, there was a statistically significant difference regarding certain aspects of goal setting. For instance, respondents knew what they wanted from the study programme $\chi^{2}(2)=10.372, p=0.016$, with a mean rank score of 110.69 for respondents with under a year of work experience, 124.73 for respondents with 1-3 years of work experience, 125.06 for students with 3-5 years of work experience and 163.02 for respondents with more than 5 years of work experience. Similarly, work experience had an impact on specific variables attributed to the indicator of technical readiness, exam preparation and stress management. 
Table 2. Correlations between variables of stress management indicator.

\begin{tabular}{|c|c|c|c|c|c|c|c|c|}
\hline & & & $\begin{array}{l}\text { I Love Attending } \\
\text { Classes. }\end{array}$ & $\begin{array}{l}\text { I Am Physically } \\
\text { Drained When I } \\
\text { Am Studying. }\end{array}$ & $\begin{array}{l}\text { I Feel Motivated } \\
\text { Whenever I Am } \\
\text { Studying. }\end{array}$ & $\begin{array}{l}\text { I Fear Not Doing } \\
\text { Well for My } \\
\text { Assignments } \\
\text { /Assessments. }\end{array}$ & $\begin{array}{l}\text { I Am Demoralised } \\
\text { When I Do Not Meet the } \\
\text { Expectations I Set for } \\
\text { Myself in My Studies. }\end{array}$ & $\begin{array}{l}\text { I Do Not Worry about } \\
\text { Not Submitting My } \\
\text { Assignment on Time. }\end{array}$ \\
\hline \multirow[t]{18}{*}{$\begin{array}{l}\text { Spearman's } \\
\text { rho }\end{array}$} & I love attending classes. & $\begin{array}{l}\text { Correlation } \\
\text { Coefficient }\end{array}$ & 1.000 & $0.302 * *$ & $0.610^{* *}$ & -0.014 & -0.083 & $-0.143 *$ \\
\hline & & Sig. (2-tailed) & & 0.000 & 0.000 & 0.810 & 0.145 & 0.012 \\
\hline & & $\mathrm{N}$ & 309 & 309 & 309 & 309 & 309 & 309 \\
\hline & $\begin{array}{l}\text { I am physically drained } \\
\text { when I am studying. }\end{array}$ & $\begin{array}{l}\text { Correlation } \\
\text { Coefficient }\end{array}$ & $0.302 * *$ & 1.000 & 0.410 ** & $0.249 * *$ & $0.144^{*}$ & -0.043 \\
\hline & & Sig. (2-tailed) & 0.000 & & 0.000 & 0.000 & 0.011 & 0.456 \\
\hline & & $\mathrm{N}$ & 309 & 309 & 309 & 309 & 309 & 309 \\
\hline & $\begin{array}{c}\text { I feel motivated } \\
\text { whenever I am studying. }\end{array}$ & $\begin{array}{l}\text { Correlation } \\
\text { Coefficient }\end{array}$ & $0.610^{* *}$ & $0.410^{* *}$ & 1.000 & 0.107 & 0.083 & -0.014 \\
\hline & & Sig. (2-tailed) & 0.000 & 0.000 & & 0.060 & 0.144 & 0.811 \\
\hline & & $\mathrm{N}$ & 309 & 309 & 309 & 309 & 309 & 309 \\
\hline & $\begin{array}{l}\text { I fear not doing well for } \\
\text { my assignments } \\
\text { /assessments. }\end{array}$ & $\begin{array}{l}\text { Correlation } \\
\text { Coefficient }\end{array}$ & -0.014 & $0.249^{* *}$ & 0.107 & 1.000 & $0.597^{* *}$ & $0.278^{* *}$ \\
\hline & & Sig. (2-tailed) & 0.810 & 0.000 & 0.060 & & 0.000 & 0.000 \\
\hline & $\begin{array}{l}\text { I am demoralised when I } \\
\text { do not meet the } \\
\text { expectations I set for } \\
\text { myself in my studies. }\end{array}$ & $\mathrm{N}$ & 309 & 309 & 309 & 309 & 309 & 309 \\
\hline & & $\begin{array}{l}\text { Correlation } \\
\text { Coefficient }\end{array}$ & -0.083 & $0.144^{*}$ & 0.083 & $0.597^{* *}$ & 1.000 & $0.324^{* *}$ \\
\hline & & Sig. (2-tailed) & 0.145 & 0.011 & 0.144 & 0.000 & & 0.000 \\
\hline & $\begin{array}{l}\text { I do not worry about not } \\
\text { submitting my } \\
\text { assignment on time. }\end{array}$ & $\mathrm{N}$ & 309 & 309 & 309 & 309 & 309 & 309 \\
\hline & & $\begin{array}{l}\text { Correlation } \\
\text { Coefficient }\end{array}$ & $-0.143 *$ & -0.043 & -0.014 & $0.278^{* *}$ & $0.324^{* *}$ & 1.000 \\
\hline & & Sig. (2-tailed) & 0.012 & 0.456 & 0.811 & 0.000 & 0.000 & \\
\hline & & $\mathrm{N}$ & 309 & 309 & 309 & 309 & 309 & 309 \\
\hline
\end{tabular}

**. Correlation is significant at the 0.01 level (2-tailed). *. Correlation is significant at the 0.05 level (2-tailed). 
Table 3. The number of respondents with work experience.

\begin{tabular}{cccc}
\hline Have You Ever Worked during Your Studies? & $\boldsymbol{n}$ & Mean Rank & Sum of Ranks \\
\hline No & 63 & 129.30 & 8146.00 \\
\hline Yes & 246 & 161.58 & $39,749.00$ \\
\hline Total & 309 & & \\
\hline
\end{tabular}

\subsection{Challenges for Students' Self-Directedness}

The analysis of variance (ANOVA) showed the statistical significance of differences $(F=4.208 ; p=0.000)$ between the variables describing how students monitor the level of their achievements and how they feel about what should be learnt during the course. The above-mentioned variables are attributed to the indicator "goal setting". ANOVA calculation also revealed a statistically significant relationship between the variables demonstrating whether the students knew what they are supposed to do when studying and whether they realized what was required from them during tests and examinations $(F=$ $12.117 ; p=0.000$ ). These findings indicate that the respondents found it difficult to monitor their learning process and that they experience challenges during the exams or tests. Analysis of the indicator "preparation for classes" did not reveal similar findings; hence, an assumption can be made that additional pressure from the exams hinders students' self-directedness.

What is worthy of discussion is the students' perception of what information presented in class is relevant and how they coped with its abundance. Statistically significant differences ( $F=5.071 ; p=0.000$ ) were revealed between the variables describing how students deal with looking for information for online presentations and how they feel when they fail to meet the expectations in their studies. The challenge to pick up the most crucial information results in students' inability to manage stress. The findings show that after the transition to online learning, procrastination management was also challenging for students. Students were expected to have a certain degree of self-directedness, as the sample consisted of third and fourth year students. The discovered relationships between variables measuring students' attitudes towards postponing the designated tasks and finding excuses for not studying $(F=40.090 ; p=0.000)$ indicate that procrastination was a problematic issue, which resulted in the inability to self-direct their studies.

\section{Discussion}

The study shows that the majority of the surveyed students perceived they were best prepared for the elements of self-directed learning that required a certain degree of technological preparation (technical readiness, assignment preparation and note-taking capability), which means that the students had the much needed technological skills for self-directed learning while studying online. This is in line with the results of other researchers [34-37] who found that students have the necessary skills, infrastructure and solutions required for online learning.

However, Martin, Stamper and Flowers [34] noted that, even before the COVID19 pandemic, technical readiness alone did not guarantee a successful online learning experience. Such findings are consistent with the results of the present research study.

The study conducted by Khiat [10] revealed that the students had more confidence regarding the indicators of "time management" and "procrastination management" (4.99 and 4.97, respectively). The current study draws its data on the survey completed during the pandemic. Thus, as it could be expected, the mean scores for the "time management" and "procrastination management" indicators are lower (4.64 and 4.32, respectively). The students seem to lack a sufficiently developed degree of self-directedness that would allow them to stay on track with the learning, not get distracted and complete their assignments. Zureick, Burk-Rafel, Purkiss and Hortsch [38] warned against the dangerous impact that distractions had on students during video classes. The warning is as relevant as ever, with all the classes relying on the students staying focused on their screens. Different distractions 
can result in procrastination, and procrastination can result in a build-up of unfinished assignments, resulting in psychological discomfort before and during the examination session.

Procrastination is not the only aspect that explains the students' difficulty to manage stress. Sahu [2] voiced concerns regarding the impact of COVID-19 on their mental and physical health. The lack of face-to-face communication and being in isolation are known to cause anxiety among learners $[39,40]$. Interestingly enough, this anxiety is not the result of a technical ineptitude, i.e., no correlation between stress management and technical readiness was established in the current study. Instead, stress is caused by procrastination and a lack of time management capability. This finding is consistent with the findings of Limone et al. [41]: Anxiety rising from a failure to keep up with the learning process and the piling up workload may cause students to lose confidence in their ability to manage their learning and eventually resulting in failure to direct their learning. The findings of the current study suggest that helping students reduce their stress levels may develop students' self-directedness.

Larson et al. [42] reported a favourable effect of simulated working environments on student self-directed learning. The findings presented in the current paper also suggest that involvement in real work organizations can positively affect specific aspects of selfdirectedness, such as time management and preparation for classes. As the majority of the present research participants had some work experience (ranging from 1 to $\geq 5$ years), the authors consider that further investigation is required to determine the full extent of the influence of student employment on their self-directedness.

The present study identified stress management as one of the most problematic factors of self-directedness for sustainable learning. Thus, further research is recommended to determine its exact causes. This would deepen our understanding of the possible actions aimed at improving sustainable learning in HE by enhancing the university students' self-directed learning.

\section{Conclusions}

The present study aimed at establishing Lithuanian university students' preparedness for sustainable learning. For this purpose, the extent of their self-directedness was explored by analysing their perspectives on ten indicators of self-directed learning and by investigating the challenges for self-directedness as perceived by the students.

The general conclusion of the research study is that the study participants were only partially prepared for sustainable learning, which requires a high level of self-directedness and that is a transformative learning experience involving a great deal of effort, flexibility and engagement on the students' behalf. The findings show that the study participants were best prepared in terms of their digital competencies (technical readiness, note-taking capability and assignment preparation capability). Such preparedness allows for effective involvement in the learning process and is relevant for self-directed learning. However, it should be borne in mind that even though digital competencies are essential for selfdirectedness in online learning, they alone cannot support sustainable learning.

It can also be concluded that, on the one hand, the students had a certain degree of preparedness regarding their research capability, the capability of goal setting, time management, exam preparation, online class readiness and procrastination management. On the other hand, these findings also suggest that the students faced some difficulties. More specifically, self-directedness in learning is a complex construct, which requires students to set goals for their learning and to pursue them constructively and consistently. The findings show that some students lacked confidence and/or faced some challenges regarding goal setting, e.g., some students did not understand what they had to do or what was required of them during the course and some did not monitor their progress at different stages of the course, while some did not understand what was required of them while taking tests or exams. 
The current research results also revealed that some students struggled to prepare for their online classes as they could not distinguish the most important information and could not cope with its abundance, which correlated with their inability to manage stress. It should also be pointed out that some students faced the challenge of failing to manage their time effectively, and that some of them gave in to procrastination. The abundance of distractions available online might have played a pivotal role in the so-called digital natives' perceived inability to manage their time and to take control of their learning.

The most alarming findings of the present research are related to the student-perceived challenge caused by their inability to manage stress. The findings suggest that the lack of time management and procrastination management capabilities could have contributed to high stress levels caused by the adverse effects of the COVID-19 pandemic and the unplanned transition to online learning. Significant stress levels could have hindered the students' self-directedness, which could have negatively impacted sustainable learning. Thus, it is evident that these findings call for action. University teachers should support the students who face such challenges, as the inability to manage stress poses serious threats to their move towards sustainable learning.

The present study is innovative as it is the first study in this field conducted in Lithuania. Even though the research was conducted relative to four universities in Lithuania, its results are valuable as they deepen our understanding of student preparedness for sustainable learning from the perspective of their self-directedness and provide insights regarding student-perceived challenges, which are essential for fostering sustainable learning in higher education.

Author Contributions: Conceptualization, N.B., R.L., J.S. and J.Š.; methodology, N.B., R.L. and J.Š.; software, R.L. and J.Šs; validation, R.L. and J.Š.; investigation, N.B., R.L., J.S. and J.Š.; resources, N.B., R.L., J.S. and J.Š.; data curation, N.B., R.L. and J.Š.; writing—original draft preparation, N.B., R.L., J.S. and J.Š.; writing—review and editing, N.B., R.L. and J.Šs.; visualization, R.L. and J.Š.; All authors have read and agreed to the published version of the manuscript.

Funding: This research received no external funding.

Institutional Review Board Statement: Not applicable.

Informed Consent Statement: Informed consent was obtained from all subjects involved in the study. The study was conducted according to the guidelines of the Declaration of Helsinki. Ethical review and approval were not necessary.

Data Availability Statement: All data are available from the corresponding author upon reasonable request.

Conflicts of Interest: The authors declare no conflict of interest.

\section{References}

1. Aucejo, E.M.; French, J.; Araya, M.P.U.; Zafar, B. The impact of COVID-19 on student experiences and expectations: Evidence from a survey. J. Public Econ. 2020, 191, 104271. [CrossRef]

2. Sahu, P. Closure of universities due to coronavirus disease 2019 (COVID-19): Impact on education and mental health of students and academic staff. Cureus 2020, 12, e7541. [CrossRef]

3. Marinoni, G.; Van't Land, H.; Jensen, T. The impact of Covid-19 on higher education around the world. In IAU Global Survey Report; International Association of Universities: Paris, France, 2020.

4. Burgess, S.; Sievertsen, H.H. Schools, Skills, and Learning: The Impact of COVID-19 on Education; International Association of Universities (IAU); UNESCO House: Paris, France, 2020.

5. Franchi, T. The impact of the Covid-19 pandemic on current anatomy education and future careers: A student's perspective. Anat. Sci. Educ. 2020, 13, 312-315. [CrossRef]

6. Sterling, S. Sustainable Education: Re-Visioning Learning and Change. Schumacher Briefings; Schumacher UK, CREATE Environment Centre: Bristol, UK, 2001.

7. Hopkins, C.; McKeown, R. Education for sustainable development: An international perspective. In Education and Sustainability: Responding to the Global Challenge; Commission on Education and Communication, IUCN: Gland, Switzerland; Cambridge, UK, 2002; p. 13. 
8. McKeown, R.; Hopkins, C.A.; Rizi, R.; Chrystalbridge, M. Education for Sustainable Development Toolkit; Energy, Environment and Resources Center, University of Tennessee: Knoxville, TN, USA, 2002; p. 2002.

9. Hays, J.; Reinders, H. Sustainable learning and education: A curriculum for the future. Int. Rev. Educ. 2020, 66, 29-52. [CrossRef]

10. Khiat, H. Academic performance and the practice of self-directed learning: The adult student perspective. J. Furth. High. Educ. 2017, 41, 44-59. [CrossRef]

11. Cebrián, G.; Junyent, M. Competencies in Education for Sustainable Development: Exploring the Student Teachers' Views. Sustainability 2015, 7, 2768-2786. [CrossRef]

12. Katayama, J.; Gough, S. Developing sustainable development within the higher education curriculum: Observations on the HEFCE strategic review. Environ. Educ. Res. 2008, 14, 413-422. [CrossRef]

13. Wiek, A.; Withycombe, L.; Redman, C.L. Key competencies in sustainability: A reference framework for academic program development. Sustain. Sci. 2011, 6, 203-218. [CrossRef]

14. Evans, T.L. Competencies and Pedagogies for Sustainability Education: A Roadmap for Sustainability in Studies Program Development in Colleges and Universities. Sustainability 2019, 11, 5526. [CrossRef]

15. Barth, M.; Godemann, J.; Rieckmann, M.; Stoltenberg, U. Developing key competencies for sustainable development in higher education. Int. J. Sustain. High. Educ. 2007, 8, 416-430. [CrossRef]

16. Cebrián, G.; Junyent, M.; Mulà, I. Competencies in Education for Sustainable Development: Emerging Teaching and Research Developments. Sustainability 2020, 12, 579. [CrossRef]

17. Blake, J.; Sterling, S.; Goodson, I. Transformative learning for a sustainable future: An exploration of pedagogies for change at an alternative college. Sustainability 2013, 5, 5347-5372. [CrossRef]

18. Mezirow, J. Transformative Learning as Discourse. J. Transform. Educ. 2003, 1, 58-63. [CrossRef]

19. Sterling, S. Transformative learning and sustainability: Sketching the conceptual ground. Learn. Teach. High. Educ. 2011, 5, 17-33.

20. Entwistle, N. Approaches to learning and forms of understanding. Teach. Learn. High. Educ. 1998, 72, 98.

21. Biggs, J. What the student does: Teaching for enhanced learning. High. Educ. Res. Dev. 1999, 18, 57-75. [CrossRef]

22. Struyven, K.; Dochy, F.; Janssens, S. Students' perceptions about evaluation and assessment in higher education: A review. Assess. Eval. High. Educ. 2005, 30, 325-341. [CrossRef]

23. Shephard, K.; Harraway, J.; Lovelock, B.; Mirosa, M.; Skeaff, S.; Slooten, L.; Strack, M.; Furnari, M.; Jowett, T.; Deaker, L. Seeking Learning outcomes appropriate for 'education for sustainable development' and for higher education. Assess. Eval. High. Educ. 2015, 40, 855-866. [CrossRef]

24. Burkšaitienè, N.; Šliogerienè, J. Lithuanian undergraduate students' approaches to learning English for Specific Purposes. J. Educ. Cult. Soc. 2021, 12, 469-477. [CrossRef]

25. Sandars, J.; Walsh, K. Self-directed learning. Educ. Prim. Care 2016, 27, 151-152. [CrossRef]

26. Blaschke, L.M. Using social media to engage and develop the online learner in self-determined learning. Res. Learn. Technol. 2014, 22, 21635. [CrossRef]

27. Brydges, R.; Carnahan, H.; Rose, D.; Dubrowski, A. Comparing self-guided learning and educator-guided learning formats for simulation-based clinical training. J. Adv. Nurs. 2010, 66, 1832-1844. [CrossRef]

28. Merriam, S.B. Andragogy and adult learning: Pillars of adult learning theory. In The New Update on Adult Learning Theory; Merriam, S.B., Ed.; Jossey-Bass: San Francisco, CA, USA, 2001.

29. Garrison, D.R. Self-Directed Learning: Toward a Comprehensive Model. Adult Educ. Q. 1997, 48, 18-33. [CrossRef]

30. Hiemstra, R. Self-directed learning. In The International Encyclopedia of Education, 2nd ed.; Husen, T., Postlethwaite, T.N., Eds.; Pergamon Press: Oxford, UK, 1994.

31. Gibbons, M. The Self-Directed Learning Handbook: Challenging Adolescent Students to Excel; Jossey-Bass: San Francisco, CA, USA, 2002.

32. Brookfield, S.D. International Handbook of Education for the Changing World of Work; Springer Science+Business Media: Dordrecht, The Netherlands, 2009; ISBN 978-1-4020-5280-4.

33. Leal Filho, W.; Raath, S.; Lazzarini, B.; Vargas, V.R.; de Souza, L.; Anholon, R.; Quelhas, O.L.G.; Haddad, R.; Klavins, M.; Orlovic, V.L. The role of transformation in learning and education for sustainability. J. Clean. Prod. 2018, 199, 286-295. [CrossRef]

34. Martin, F.; Stamper, B.; Flowers, C. Examining Student Perception of Readiness for Online Learning: Importance and Confidence. Online Learn. 2020, 24, 38-58. [CrossRef]

35. Tang, Y.M.; Chen, P.C.; Law, K.M.; Wu, C.H.; Lau, Y.Y.; Guan, J.; He, D.; Ho, G.T. Comparative analysis of Student's live online learning readiness during the coronavirus (COVID-19) pandemic in the higher education sector. Comput. Educ. 2021, $168,104211$. [CrossRef] [PubMed]

36. Jamalpur, B.; Chythanya, K.R.; Kumar, K.S. A Comprehensive Overview of Online Education-Impact on Engineering Students during COVID-19. Mater. Today Proc. 2021, in press. [CrossRef]

37. García-Morales, V.J.; Garrido-Moreno, A.; Martín-Rojas, R. The transformation of higher education after the COVID disruption: Emerging challenges in an online learning scenario. Front. Psychol. 2021, 12, 196. [CrossRef] [PubMed]

38. Zureick, A.H.; Burk-Rafel, J.; Purkiss, J.A.; Hortsch, M. The interrupted learner: How distractions during live and video lectures influence learning outcomes. Anat. Sci. Educ. 2018, 11, 366-376. [CrossRef] [PubMed] 
39. Yingjing, X.; Zhongyong, W. Investigation and Analysis of Learning Anxiety for Online Teaching in Universities and Colleges under the Epidemic Situation. In Proceedings of the 4th International Conference on Digital Technology in Education, Busan, Korea, 15-17 September 2020; pp. 20-25.

40. Hilliard, J.; Kear, K.; Donelan, H.; Heaney, C. Students' experiences of anxiety in an assessed, online, collaborative project. Comput. Educ. 2020, 143, 103675. [CrossRef]

41. Limone, P.; Sinatra, M.; Ceglie, F.; Monacis, L. Examining Procrastination among University Students through the Lens of the Self-Regulated Learning Model. Behav. Sci. 2020, 10, 184. [CrossRef] [PubMed]

42. Larson, J.; Jordan, S.S.; Lande, M.; Weiner, S. Supporting Self-Directed Learning in a Project-Based Embedded Systems Design Course. IEEE Trans. Educ. 2020, 63, 88-97. [CrossRef] 